\title{
THE ALCYONARIA OF FUNAFUTI.
}

PART I.

BY THOMAS WHITELEGGE.

Zoologist, Australian Museum. 

[X.]

\section{THE ALCYONARIA.}

\section{Part I.}

\section{By Thomas Whitelegge,}

Zoologist, Australian Museum.

The Alcyonaria collected at the Ellice Group by Mr. O. Hedley, prove to be of more than ordinary interest, inasmuch as the Collection now dealt with includes four new species, and many rare or but little known forms.

There are three species of the genus Sarcophytum, one of which was originally described by Dana as Alcyonium latum, from Fiji; herein it is referred to the genus Sarcophytum, to which it undoubtedly belongs.

The genus Lobophytum is represented by six or seven species; two are described as new, and four others have been re-described and illustrated, with a view to aid in their determination in the future.

In dealing with the species described by the earlier authors, there is a considerable amount of doubt as to their specific identity, from the fact that the characters afforded by the spicules have generally been ignored, and only the external features given. In such cases 1 have thought it better to accept the species, when they agreed fairly well with the descriptions, rather than describe them as new.

Under this category are included Alcyonium tuberculosum, Q. \& G., A. confertum, Dana, and A. viride, Q. \& G. The latter appears to differ greatly from the other species under notice, and Studer refers it to the genus Lobularia in his account of the Alcyonaria of S.M.S. "Gazelle."* Judging by the spicules alone, the species herein enumerated and referred to the genus Lobophytum are very heterogeneous, displaying great variation in the size and also in the tuberculation of the larger spicules; the tubercles are not in whorls but are irregularly scattered, this is so in $L$. tuberculosum, $L$. confertum, and $L$. densum, which in this respect are closely allied to L. marenzelleri, and also in the size of the siphonozooids, which are minute and almost rudimentary.

* Monatsb. Akad. Wiss. Berlin, 1878, p. 634. 
The Nephthyidae are represented by two species of Spongodes, one-S. pallida-being regarded as new.

Of the genus Siphonogorgia no less than three out of the seven known species are in the Collection, together with a new species possessing very large spicules, the external ones of which resemble those of Spongodes.

I have again to acknowledge my obligation to my colleague, Mr. Edgar R. Waite, for the admirable pen and ink drawings, from which the accompanying illustrations were photographically reproduced.

Mr. Charles Hedley supplies the following field notes :-

"The Alcyonida, such as Lobophytum and Sarcophytum, especially flourished on the numerous small reefs which stud the lagoon, where they grew from low water to as deep as the eye could follow. Like the hard corals with which they were interspersed, they loved clear, smooth water, and a rocky bottom, and could not endure sand or mud. So plentiful were they in such spots, that I have often walked for twenty or thirty paces treading upon Alcyonaria continuously. So much do these resemble in a general way some of the hard corals, among which they grow, that I have often stooped to feel whether the object of my attention were hard or soft. On shady days the polyps might be seen fully exserted, but in bright sunshine they were invariably retracted. All the specimens collected were taken at low water by wading on the lagoon reefs opposite the anchorage.

"The Nephthyidae, embracing Spongodes and Siphonogorgia, could not be reached but by one having steam power at command. The only day a steam launch was placed at my disposal, I spent the time dragging tangles across and along the steep and narrow slope west of the atoll, between forty and seventy fathoms. From this rocky mountain side were procured one species of Spongodes, four species of Siphonogorgia, and a number of Gorgonias." These latter will be dealt with in the next Part.

\section{ALCYONARIA.}

\section{Family ALCYONID $\AA$.}

\section{Sarcophytum Glaudum, Quoy \& Gaim.}

Sarcophytum glaucum, Quoy \& Gaim., Voy. Astrolabe, Zoophytes, iv., p. 270, pl. xxii., figs. 11-12 ; Marenzeller, Zool. Jahrb., Bd. i., 1886, p. 352, pl. ix., fig. 12 ; Wright \& Studer, Chall. Rep., Zool., xxxi., p. 248, pl. xlii., fig. 3 .

Four well preserved specimens, with the polyps mostly extended. 
Sarcophytum trocheliophorum, var. amboinense, Marenz.

Sarcophytum trocheliophorum, var. amboinense, Marenz., Zool. Jahrb., Bd. i., 1886, p. 361, pl. ix., tig. 6 ; Wright \& Studer, Chall. Rep., Zool., xxxi., p. 249, pl. xli., fig. 11.

One small specimen, the polyps are quite retracted, the siphonozooids are distinct and disposed in circles. The short thick spicules are characteristic of this form. (See fig. $6 c$ on Marenzeller's plate.)

\section{Sarcophytum latum, Dana.}

$$
\text { (Plate x., figs. } 1 a-f \text {.) }
$$

Alcyonium latum, Dana, Zooph. U.S. Explor. Exped., pl. lviii., figs. 6, $a, b, b$; Synop. Rep. Zooph., 1859, p. 125.

The single example obtained, differs slightly from the type as figured by Dana; it is smaller, more depressed, and the lobes are fewer.

The sterile column is well developed, it is $55 \mathrm{~mm}$. high at its highest point, and $30 \mathrm{~mm}$. at its lowest ; the surface is longitudinally sulcate and very harsh to the touch.

The capitular margin is a little swollen, but not at all revolute, the upper surface generally presents a minutely beaded appearance, due to the elevation of the walls surrounding the orifices of the polyps.

The autozooids, which are $1 \mathrm{~mm}$. apart, are encircled by six or seven siphonozooids, the latter being also common to the encircling series of adjoining autozooids, as shown in Dana's fig. $6 a$.

The cœnenchyma spicules are abundant, and consist of fusiform, and of subcylindrical spindles, studded with whorled, granular, or spiny tubercles. Size- $\cdot 3$ by $\cdot 08, \cdot 4$ by $\cdot 1, \cdot 3$ by $\cdot 15$, $\cdot 35$ by $\cdot 15 \mathrm{~mm}$. In addition to these, there are a few crosses and comparatively smooth spiny spindles.

The spicules of the cortex are tuberculated clubs, which form a very dense crust, they are variable at the blunt end, some are broad and others obliquely pointed. Size -12 by $\cdot 03, \cdot 2$ by $\cdot 04 \mathrm{~mm}$.

The specimen has the same general shape as that figured by Dana, consisting of two subfoliate expansions ; there is evidently an error in fig. 7, the right half having the sterile column coloured and dotted to represent polyps similar to those on the capitular surface.

The spirit specimen is dark stone colour. 
Lobophytum PaUCIFLORUM, Ehr., var. validum, Marenz.

Lobophytum pauciflorum, Ehr., var. validum, Marenz., Zool. Jahrb., Bd. i., p. 367, pl. ix., fig. 12, $a, b, c$.

One specimen $80 \mathrm{~mm}$. long by $52 \mathrm{~mm}$. wide, the sterile column is $25 \mathrm{~mm}$. high, with a somewhat even surface, excepting at one point, where it exhibits a few transverse wrinkles.

The capitular margin is slightly thickened, and a little revolute in some parts.

The lobes of the capitulum are abruptly rounded at the summits, they are about ten in number and vary from 15 to $25 \mathrm{~mm}$. in height, 15 to $40 \mathrm{~mm}$. in width, and from 7 to $10 \mathrm{~mm}$. in their least diameter.

The autozooids are $2 \mathrm{~mm}$. apart, the walls surrounding the orifices are slightly raised, and a shade darker in colour than the rest of the surface.

The siphonozooids are numerous, small, and scarcely visible to the unassisted eye; there are from five to seven between two autozooids.

The spicules do not differ from those figured by Marenzeller.

The specimen in spirits is a dark stone colour.

LOBOPHYTUM HEDLEYI, sp. nov.

(Plate x., figs. 2a-h.)

There are three examples, exhibiting great variation in the lobation of the capitulum.

In the larger specimen the sterile column is complete, rigid, and harsh to the touch, longitudinally plicate, and measures $50 \mathrm{~mm}$. in diameter and $35 \mathrm{~mm}$. in height.

The capitulum consists of about twelve subflabellate lobes from 20 to $40 \mathrm{~mm}$. high, 25 to $45 \mathrm{~mm}$. wide, and from 5 to $8 \mathrm{~mm}$. thick.

The primary lobes are divided into three or four secondary lobes, 10 to $15 \mathrm{~mm}$. high, and 5 to $10 \mathrm{~mm}$. wide. Many of the broader lobes have a longitudinal fold commencing at the base and continued to the subtruncate apex.

In the two smaller examples, both the primary and secondary lobes are much narrower, the latter often digitate, compressed, or subcylindrical, with evenly rounded summits, the wider lobes exhibit a rather broad median longitudinal groove on at least one side; on the widest lobes the grooves are present on both sides. The primary lobes are from 8 to $30 \mathrm{~mm}$. wide, 10 to $25 \mathrm{~mm}$. high, and from 3 to $7 \mathrm{~mm}$. thick; the secondaries from 5 to $20 \mathrm{~mm}$. high, 5 to $10 \mathrm{~mm}$. wide, and from 2 to $5 \mathrm{~mm}$. in their narrow diameter. 
The autozooids are very irregularly disposed; they are few in number, and on the central regions of the lobes separated from each other by wide intervals. On the margins and summits of the lobes they are closer, and about 1 to $2 \mathrm{~mm}$. or even less apart.

The siphonozooids are numerous, distinct, and plainly visible to the unassisted eye; between the widely separated autozooids there are as many as twelve, whilst on the margins, where the autozooids are crowded, they are fewer and disposed in circles.

The spicules of the cœnenchyma consist of-

(1.) Straight rather acute ended spindles, the smaller of which are often unequal and subclavate. The tubercles are in whorls and somewhat minutely spinose. Size- $\cdot 15$ by $\cdot 03, \cdot 3$ by $\cdot 09 \mathrm{~mm}$.

(2.) Short, stout, subcylindrical, with from four to six whorls of spiny tubercles. Size- $\cdot 15$ by $\cdot 07, \cdot 2$ by $1 \mathrm{~mm}$.

In addition to the foregoing there are numerous spiny spindles and some crosses. The spicules of the cortex are rather narrow tuberculated clubs. Size- $\cdot 12$ by $\cdot 02, \cdot 15$ by $\cdot 05 \mathrm{~mm}$.

The colour in spirits is umber.

Reg. No. G. 1537.

LOBOPHYTUM MARENZELLERI, Wright \& Studer.

Lobophytum marenzelleri, Wright \& Studer, Chall. Rep., Zool. xxxi., p. 251, pl. xlii., fig. 1.

One specimen of an oval shape; $80 \mathrm{~mm}$. long and $40 \mathrm{~mm}$. wide. Only a small portion of the sterile column remains, it is $30 \mathrm{~mm}$. high. The lobation of the capitulum, autozooids, siphonozooids and spicules, agree with the published description.

The specimen is of a yellowish-white colour.

LоворнутUм тUBERculosum, Quoy \& Gaim.

$$
\text { (Plate xi., figs. } 3 a-f \text {.) }
$$

Lobophytum tuberculosum, Quoy \& Gaim., Voy. Astrolabe, Zooph., iv., p. 274, pl. xxiii., figs. 4-5.

In a small example referred to this species the sterile stem is mostly torn away, the remaining portion is $15 \mathrm{~mm}$. high and $25 \mathrm{~mm}$. wide.

The capitulum is $80 \mathrm{~mm}$. long, $60 \mathrm{~mm}$. wide, ard $20 \mathrm{~mm}$. high.

There are seven primary lobes arising from the expanded base, each bearing from five to twenty secondary round, oblong, or subreniform lobes, their height seldom exceeding their lesser diameter.

The autozooids are crowded, with the margins of the orifices deeply sunk, they are from $\cdot 5$ to $1 \mathrm{~mm}$. apart. 
The siphonozooids are exceedingly minute and the orifices difficult to see even with a strong lens. Their number is from two to four between two autozooids.

The spicules ot the cœnenchyma are straight, or curved, irregularly tuberculated spindles, displaying great variation in outline; some are cylindrical to within a short distance of the ends, where they taper rapidly to rather blunt points, others are clavate with the narrow end acute, and a few taper gradually to acute points. Size -5 by $\cdot 12,2 \cdot$ by $\cdot 4 \mathrm{~mm}$.

The cortical spicules are small clubs with tuberculate heads and spiny sharply pointed shafts. Size- $\cdot 15$ by $\cdot 04, \cdot 25$ by $\cdot 07 \mathrm{~mm}$. There are also a few smooth or slightly spiny spindles; crosses have not been observed. The colour in spirits is yellowish-gray.

\section{Lobophytum confertum, Dana.}

(Plate xi., figs. $5 a-e$.

Lobophytum confertum, Dana, U. S. Explor. Exped., Zooph., pl. lvii., fig. 7, $a, b$; Synop. Rep. Zooph., 1859, p. 125.

One specimen in which the sterile column is absent is with some hesitation referred to this species. The colony is "ery hard to the touch, and densely charged with large spicules, which can be seen with the unaided eye projecting from the broken surfaces.

The capitulum consists of eight or nine main lobes, upon which are situated a large number of secondary lobes, varying greatly in shape; on the basal expansion they are subcylindrical or compressed and are from 4 to $15 \mathrm{~mm}$. high, and 3 to $5 \mathrm{~mm}$. thick. Along the sides of the primaries the secondaries form low ridges which extend in a more or less broken manner from the bases to the summits, they are about as high as broad. The apical and subapical lobes are very variable, scarcely any two being alike; they may be round, trigonous, or much compressed, with a slight longitudinal groove, and the margins folded towards each other; they are from 5 to $15 \mathrm{~mm}$. high, 3 to $10 \mathrm{~mm}$. in their broad, and from 3 to $5 \mathrm{~mm}$. in their narrow diameter.

The autozooids are evenly distributed, the marginal walls of the orifices deeply sunk; they are tolerably uniformly spaced, being $1 \mathrm{~mm}$. apart.

The siphonozooids are so minute that a high magnifying lens fails to render them visible.

The cœnenchyma exhibits when viewed in transverse section a large number of canals from 5 to $2 \mathrm{~mm}$. in diameter; the walls are thickly charged with very large tuberculate spindles.

The tubercles are small, close, rather indistinctly whorled and minutely granular; some of the larger spicules have spines only, 
they appear to be less opaqu than those bearing tubercles, and the spines can be seen radiating from the axial region of the spicule.

The spicules of the cœnenchyma vary considerably, and may be enumerated as follows :-

(1.) Large, curved or rarely straight, very variable both in the amount of curvature, and the acuteness of the points; most of those evenly curved, whether boomerang, bow or $f$-shaped, have moderately sharp points, whilst those unequally curved usually have one end blunt. Size-1.7 by $\cdot 25,2.5$ by $\cdot 4 \mathrm{~mm}$.

(2.) Straight, fusiform, equally tapering to sharp points. Size- 1.4 by $\cdot 22 \mathrm{~mm}$. $15 \mathrm{~mm}$.

(4.) Large, straight, or curved, fusiform with spines only. Size $-1 \cdot 4$ by $\cdot 22,2 \cdot$ by $45 \mathrm{~mm}$.

The cortical spicules consist of :-

(1.) Comparatively smooth fusiform spindles, with small tubercles or spines. Size- 45 by $.08 \mathrm{~mm}$.

(2.) Straight, spiny, aimost cylindrical. Size--.35 by $.05 \mathrm{~mm}$.

(3.) Clubs with tuberculate heads and long spiny shafts. Size -2 by $\cdot 04, \cdot 25$ by $\cdot 05 \mathrm{~mm}$.

The colour is coffee-brown, but this may be due to staining caused by contact with other objects in the cask in which the specimen was preserved. This is highly probable, as a second example which at first sight was thought to be distinct, proves to be the same, or perhaps a variety.

The colour of the second specimen is pale glaucus or sage green, the primary lobes are not so high, the secondary lobes are shorter, thicker, and mostly in contact, each lobe being adapted to the shape of contiguous lobes. A small portion of the barren stem is present and exhibits a few longitudinal plications, but it is comparatively smooth to the touch. Other characters, such as the size of the autozooids, their distance apart, the rudimentary siphonozooids, and the spicules, are very similar, and offer no marked points of difference.

\section{LOBOPHYTUM DENSUM, sp. nov.}

\section{(Plate xi., figs. $4 a-h$.)}

The colony is $70 \mathrm{~mm}$. long, $45 \mathrm{~mm}$. wide, and $60 \mathrm{~mm}$. high. About half of the sterile column is wanting, the height of the remaining portion varies from 15 to $35 \mathrm{~mm}$. in height. The cœnenchyma is thickly charged with large spicules, giving the stem when viewed in transverse section a solid appearance, the longitudinal canals are not perceptible to the unassisted eye. 
The capitulum consists of numerous digitate lobes, mostly simple, but some of the larger centrally situated give off from three to five secondaries. The lobes are more or less compressed with obtusely rounded summits, they are from 5 to $35 \mathrm{~mm}$. high, 4 to $12 \mathrm{~mm}$. in their narrow, and 7 to 15 in their broad diameter.

The autozooids are few and distant at the bases of the lobes, elsewhere they are evenly distributed, and are from $\cdot 5$ to $1 . \mathrm{mm}$. apart

The siphonozooids are minute, and the orifices difficult to distinguish even with a strong lens.

The cœnenchyma spicules are very large, and exist in such numbers that the colony is almost of stony hardness. They usually consist of straight or but little curved tuberculated spindles, somewhat thick in the middle and tapering to sharp points, some few have one end blunt, and occasionally branched; the tubercles are irregularly disposed.

The measurements of the spicules are as follows :-

(1.) Large, fusiform, with simple spine-like tubercles, and usually with a transverse median constriction. Size $-1 \cdot$ by $\cdot 2$, $2 \cdot 4$ by $\cdot 5$.

(2.) Large, fusiform, subcylindrical or subclavate, closely tuberculate, the tubercles are thickly studded with minute spiny warts. Size- $\cdot 8$ by $\cdot 2,1 \cdot 4$ by $\cdot 35,2 \cdot$ by $\cdot 5,4 \cdot$ by $\cdot 9 \mathrm{~mm}$.

(3.) Smaller fusiform, strongly but distantly tuberculate. Size- $\cdot 35$ by $\cdot 1, \cdot 65$ by $\cdot 15 \mathrm{~mm}$.

(4.) Small fusiform, comparatively smooth, with spines. Size$\cdot 5$ by $\cdot 09, \cdot 6$ by $\cdot 1 \mathrm{~mm}$.

The cortical spicules consist of short spiny spindles and clubs.

(1.) Spindles : Size- $\cdot 25$ by $\cdot 03$.

(2.) Clubs : Size- $\cdot 1$ by $\cdot 03, \cdot 13$ by $\cdot 03 \mathrm{~mm}$.

The colour in spirits is pale brown, with the grooves and pits darker.

Reg. No. G. 1541.

Lobularia (?) viride, Quoy \& Gaim.

(Plate xii., figs. 6a-d.)

Alcyonum viride, Quoy \& Gaim., Voy. l'Astrolabe, iv., p. 272, pl. xxiii., figs. $22-23$.

Ten specimens, very soft and flexible, displaying great variation in thę terminal lobes, some being cylindrical, others broad and compressed or forming a series of rounded undulations on the summits of the flabellate branches.

The sterile column in a perfect example is largely developed, it is $60 \mathrm{~mm}$. high and $50 \mathrm{~mm}$. in diameter. 
The capitulum consists of five primary branches from 20 to $50 \mathrm{~mm}$. wide, 20 to $40 \mathrm{~mm}$. high, and from 5 to $8 \mathrm{~mm}$. thick. The secondary lobes are from 8 to $30 \mathrm{~mm}$. high, 7 to $25 \mathrm{~mm}$. wide, and from 3 to $7 \mathrm{~mm}$. thick, with broadly rounded apices.

In another example the primary branches are from 50 to $75 \mathrm{~mm}$. wide, 20 to $50 \mathrm{~mm}$. high, and from 5 to $7 \mathrm{~mm}$. thick, the upper margins having only slight indications of lobes, the central primary branch has nine low rounded elevations, the highest being $10 \mathrm{~mm}$. high and about the same in width.

The autozooids are irregularly disposed from 1 to $5 \mathrm{~mm}$. apart, and are much closer together on margins and apices of the lobes than on the intervening spaces.

The siphonozooids are numerous, large and visible to the unaided eye, varying greatly as to the number between the autozooids; usually there are two or three to $1 \mathrm{~mm}$.

The cœnenchyma of the sterile stem and of the capitulum is charged with similar spicules, and I have been unable to detect any special dermal layer in the capitulum. There exists a cortical layer of spicules on the barren stem, consisting of small almost smooth clubs with very few tubercles, and some short irregularly shaped spindles with blunt ends.

The cœnenchyma spicules are as follows:-

(1.) Tuberculed spindles with the tubercles in well marked zones. Size -2 by $\cdot 05, \cdot 35$ by $\cdot 1 \mathrm{~mm}$.

(2.) Short, subcylindrical, with from four to six whorls of tubercles. Size- $\cdot 19$ by $\cdot 08, \cdot 23$ by $1 \mathrm{~mm}$.

Cortical spicules of the sterile column :-

(1.) Smooth spindles, with a few low rounded tubercles. Size- $\cdot 1$ by $\cdot 02 \mathrm{~mm}$.

- (2.) Clubs with smooth tubercles. Size- $\cdot 15$ by $\cdot 03 \mathrm{~mm}$.

The colour in spirits is olive-gray.

There are two small specimens which differ in being of a delicate greenish-yellow, and the sterile stem is rougher to the touch, but the other characters appear to be the same, and the spicules are indistinguisbable from those of the typical form.

\section{FAMILY NEPHTHYID $Æ$.}

\section{Sub-Family Spongodine.}

SPONGODES PALLIDA, sp. nov.

(Plate xii., figs. $7 a-c$.)

The colony arises from an encrusting base $15 \mathrm{~mm}$. long, $8 \mathrm{~mm}$. wide, and from 1 to $2 \mathrm{~mm}$. thick. 
There are three stems about equal in height and in distance apart; they are $10 \mathrm{~mm}$. high, 3 to $5 \mathrm{~mm}$. in diameter at their bases, and from 6 to $9 \mathrm{~mm}$. at their summits.

The polyps commence at the bases of the stems, where they are arranged singly, irregularly, and at a considerable distance apart.

On the upper portions of the stems the polyps are in clusters of from three to twelve, and arise from very short secondary branches; on the central stem there are about thirteen such clusters, the largest of which is $3 \mathrm{~mm}$. high and $5 \mathrm{~mm}$. wide.

The polyp heads together with the stalks are from 1 to $1.5 \mathrm{~mm}$. high, and from 07 to $1 \mathrm{~mm}$. in diameter.

The solitary polyps are given off from the stem at right angles, whilst the clusters on the branches are radiate, and the apertures of many of the lower ones are directed towards the base of the stem.

The stem spicules are arranged transversely, and consist of slightly curved spindles with obtuse ends, having their surfaces closely beset with low rounded tubercles, which are generally smooth, but in some of the larger forms they are minutely denticulate.

Size- $\cdot 5$ by $\cdot 09,1 \cdot 5$ by $\cdot 2 \mathrm{~mm}$.

The spicules of the branches are shorter, stouter, and a little more curved than those of the stem.

The polyp heads have at their bases a number of transversely arranged spiny spindles with acute points. Size- -4 by $.03 \mathrm{~mm}$., .75 by $.09 \mathrm{~mm}$. From these there arise larger and longitudinally disposed spicules in pairs, each pair converging at their apices and separated at their bases. Usually one of each pair is longer and projects beyond the margin of the calyx.

These spicules are curved at the base, pointed at their free end, and covered with sharp spines. Size -.6 by $\cdot 03, \cdot 8$ by $\cdot 05 \mathrm{~mm}$. ,

The tentacular spicules are distantly spinose, and are arranged en chevron. Size- $\cdot 12$ by $02 \mathrm{~mm}$.

The colour of the colony is uniform creamy-white. Obtained by the tangles at a depth of from 40 to 70 fathoms outside the reef.

Reg. No. G. 1543.

\section{Spongodes CURVICORNIs, Wright \& Studer.}

Spongodes curvicornis, Wright \& Studer, Chall. Rep., Zool., xxxi., p. 220 , pl. xxxvi., D., figs. $2, a, b$.

One specimen dredged in about 20 fathoms in the lagoon.

The lowèr branches are connected and foliate or rosette-like as in the type specimen. 
The spindle-shaped spicules on the stem and branches are large, numerous, and easily visible to the unassisted eye; those on the main stem are arranged more or less transversely, varying greatly in size, and are much more strongly spinose than the longitudinally disposed spicules of the branches.

The colour is yellowish-white, the branches and polyps are dark reddish-purple. The larger spicules often attain to a length of $6 \mathrm{~mm}$.

\section{Sub-Family Siphonogorgine.}

\section{SiPHONOGORgIA gODEFFROYI, Kolliker.}

Siphonogorgia godeffroyi, Kolliker, Wright \& Studer, Chall. Rep., Zool., xxxi., p. 236, pl. xxxviii., fig. 4.

There are two small broken specimens which I refer to this species, the larger of which is $25 \mathrm{~mm}$. high and $5 \mathrm{~mm}$. in diameter; the apex is wanting, the remaining portion consists of an erect stem giving off eight very short branches with terminal polyps. The stem is pinkish at the base, the upper part white, and the polyps very dark red. The longitudinally arranged spicules are large, and consist of straight or curved tuberculated spindles. Size- $3 \cdot$ by $\cdot 3 \mathrm{~mm}$.

Obtained at a depth of from 40 to 70 fathoms.

\section{Siphonogorgia Pallida, Studer.}

Siphonogorgia pallida, Studer, Chall. Rep., Zool., xxxii., p. 8, pl. ii., fig. $2 a, b$.

One example preserved in formol, in a much broken condition, the actual base is wanting and the upper terminal twigs are reduced to fragments.

The colony notwithstanding its damaged condition is $130 \mathrm{~mm}$. high and $70 \mathrm{~mm}$. wide, the main stem is laterally compressed, its widest basal diameter is $8 \mathrm{~mm}$. and its narrowest $5 \mathrm{~mm}$.

At a short distance from the base a large secondary branch arises, which is slightly less robust than the primary, the general appearance is like the figure on pl. ii. of the Chall. Rep., but the main and secondary branches are more undulate.

The polyps on the lower parts of the colony are in many instances quite flush with the surface, very few projecting like those on the slender twigs.

The colour is bright brick-red with yellow polyps. 
In the walls of the canals there are numerous small spiny spindles, of a dark carmine colour, offering a striking contrast to the larger spicules which are yellowish-red by transmitted light. Size- $\cdot 15$ by $\cdot 01, \cdot 35$ by $\cdot 03 \mathrm{~mm}$.

\section{Siphonogorgia Kollikeri, Wright \& Studer.}

Siphonogorgia kollikeri, Wright \& Studer, Chall. Rep., Zool., xxxi., p. 236, pl. xxiv., fig. 2 ; Studer, Chall. Rep., xxxii., p. 7 , pl. i., fig. 2 ; pl. v., fig. 3 ; pl. vi., figs. $4-5$.

One specimen with a slightly enlarged base, and measuring $100 \mathrm{~mm}$. in height, but no doubt much higher when perfect; all the terminal twigs are broken.

The colony closely resembles the figure given by Studer, the large cone-shaped polyps being very characteristic.

The colour in spirits is coral-red.

Obtained at a depth of from 40 to 80 fathoms.

\section{Siphonogorgia macrospina, sp. nov.}

(Plate xii., figs. $8 a-d$.)

There are about twenty fragments of what appears to have been one colony. Judging by these fragments the growth was erect and in one plane, lateral branches being given off alternately at intervals of from 5 to $10 \mathrm{~mm}$., but rarely at right angles ; the largest branch measures $25 \mathrm{~mm}$. in height, and gives off two alternate branchlets about $10 \mathrm{~mm}$. apart. The thicker branches are a little compressed and $2 \mathrm{~mm}$. in diameter, the slender terminal twigs are $1 \mathrm{~mm}$. or less. The branches are rigid but exceedingly brittle owing to the large spicules and the paucity of the cœnenchyma.

The polyps occur at intervals of $3 \mathrm{~mm}$. apart, and are arranged subspirally around the twigs either singly or in pairs, they are placed obliquely to their support, and provided with a slightly projecting calvx; there is a distinct operculum composed of grouped spicules arranged like a $\Lambda$, and a collar of transversely disposed spicules below the tentacles.

The longitudinally arranged cortical spicules consist of much curved or bent spindles, they are greatly elongated with slender acute points, and the surfaces closely studded with warty tubercles.

The walls of the nutrient canals are thickly charged with long, thin, spiny rods and spindles.

The spicules are as follows :-

(1.) Large elongate curved spindles, densely covered with warty tubercles and tapering to sharp points. Size- 1.4 by $15 \mathrm{~mm}$., $2 \cdot$ by $21,3 \cdot$ by $32,4 \cdot$ by $\cdot 35,5 \cdot 5$ by $\cdot 4,6 \cdot$ by $\cdot 45 \mathrm{~mm}$. 
(2.) Long subcylindrical spiny rods and spindles, abundant in the canal walls. Size- 6 by $\cdot 02,1 \cdot 3$ by $\cdot 03,1 \cdot 8$ by $\cdot 04 \mathrm{~mm}$.

(3.) Calicular spicules, spiny subfusiform, with the free ends acute. Size- $\cdot 7$ by $12,1 \cdot$ by $\cdot 15 \mathrm{~mm}$.

(4.) Opercular spicules, distantly spinose. Size- $\cdot 3$ by $\cdot 03 \mathrm{~mm}$.

(5.) Collar spicules, curved and minutely spinose. Size-25 $\mathrm{x} \cdot 02 \mathrm{~mm}$.

The colour in spirit is bright yellow, polyps darker.

Obtained outside the reef at a depth of from 40 to 70 fathoms.

Reg. No. G. 1548. 


\section{$2 \mathrm{BHL}$ Biodiversity Heritage Library}

Whitelegge, Thomas. 1897. "X. The Alcyonaria. Part I." The Australian Museum Memoir 3(3), 211-225. https://doi.org/10.3853/j.0067-1967.3.1897.496.

View This Item Online: https://www.biodiversitylibrary.org/item/104834

DOI: https://doi.org/10.3853/j.0067-1967.3.1897.496

Permalink: https://www.biodiversitylibrary.org/partpdf/258419

\section{Holding Institution}

University of California Libraries (archive.org)

\section{Sponsored by}

MSN

\section{Copyright \& Reuse}

Copyright Status: NOT_IN_COPYRIGHT

This document was created from content at the Biodiversity Heritage Library, the world's largest open access digital library for biodiversity literature and archives. Visit BHL at https://www.biodiversitylibrary.org. 